\title{
Work addiction in Poland: adaptation of the Bergen Work Addiction Scale and relationship with psychopathology
}

\section{BACKGROUND}

Work addiction has been recognized as a potential behavioral addiction, and studies have consistently shown its negative relationship with psychosocial functioning. However, in many countries, such as Poland, very few work addiction studies are based on measures developed using an addiction framework. Against this backdrop, the Bergen Work Addiction Scale (BWAS) was adapted for use in Polish samples and its relationship with psychopathology was investigated.

\section{PARTICIPANTS AND PROCEDURE}

In a pen-and-pencil cross sectional study, the BWAS, the Adult Attention Deficit Hyperactivity Disorder SelfReport Scale, the Mini-International Personality Item Pool, and questions concerning demographic, health and workrelated variables were administered to 723 Polish employees from various professions. Their mean age was 36.37 years $(S D=11.33$, range $=20-79)$.

\section{RESULTS}

Support for a one-factor solution for the BWAS was found and the BWAS demonstrated good reliability $(\alpha=.84)$. Work addiction was significantly related to specific aspects of work (longer working time and managerial positions), personality traits (higher neuroticism), and psychopathology (depression and attention deficit hyperactivity). The prevalence of work addiction using the BWAS was $17.4 \%$ in the present sample.

\section{CONCLUSIONS}

The Polish BWAS has good psychometric properties and is a suitable scale for the assessment of work addiction based on the findings of the present study.

\section{KEY WORDS}

ADHD; addiction; depression; neuroticism; workaholism

ORGANIZATION - 1: Institute of Psychology, University of Gdansk, Gdansk, Poland · 2: University of Bergen, Bergen,

Norway · 3: Nottingham Trent University, Nottingham, UK

AUthors' Contributions - A: Study design - B: Data collection - C: Statistical analysis - D: Data interpretation .

E: Manuscript preparation · F: Literature search · G: Funds collection

Corresponding Author - Paweł Andrzej Atroszko, Ph.D., Institute of Psychology, University of Gdansk,

4 Bażyńskiego Str., 80-952 Gdansk, Poland, e-mail: p.atroszko@ug.edu.pl 


\section{BACKGROUND}

Work addiction (often referred to as 'workaholism') has been defined as "being overly concerned about work, driven by an uncontrollable work motivation, and to investing so much time and effort to work that it impairs other important life areas" (Andreassen, Hetland, \& Pallesen, 2014b, p. 8). Over the past two decades, research examining work addiction has greatly increased (Clark, Michel, Zhdanova, Pui, \& Baltes, 2016), both in terms
Paweł Andrzej Atroszko, Ståle Pallesen, Mark D. Griffiths, Cecilie Schou Andreassen of conceptual clarification and further consistent recognition regarding the correlates of work addiction (Andreassen, 2014; Andreassen \& Pallesen, 2016; Atroszko, 2012; Griffiths, 2011; Shimazu, Schaufeli, Kamiyama, \& Kawakami, 2015). Furthermore, many scholars have examined the differentiation between work addiction and work engagement as well as harmonious and obsessive passion towards work, both theoretically and empirically (e.g., Andreassen, 2014; Andreassen \& Pallesen, 2016; Burke \& Fiksenbaum, 2009; Birkeland \& Buch, 2015; Karanika-Murray, Duncan, Pontes, \& Griffiths, 2015; Karanika-Murray, Pontes, Griffiths, \& Biron, 2015; Quinones \& Griffiths, 2015; Quinones, Griffiths, \& Kakabadse, 2016; Vallerand, Paquet, Philippe, \& Charest, 2010; van Beek, Hu, Schaufeli, Taris, \& Schreurs, 2012; van Beek, Taris, Schaufeli, \& Brenninkmeijer, 2014). Studies have also demonstrated that the concepts are either slightly positively related (Shimazu \& Schaufeli, 2009) or not at all (van Beek, Taris, \& Schaufeli, 2011). Engaged workers and work addicts put comparably large amounts of time and effort into work. However, in contrast to work addicts, engaged workers remain in control, and have a non-problematic balanced life style. Work engagement is typically associated with positive outcomes, while work addiction is associated with negative outcomes (Falco et al., 2013; Shimazu \& Schaufeli, 2009; Shimazu, Schaufeli, \& Taris, 2010; van Beek et al., 2011). Reliable prevalence estimates of work addiction are sparse. To date, there have only been two nationwide studies in Norway assessing work addiction in representative samples of employees, where prevalence rates of $8.3 \%$ and $7.3 \%$ were reported (Andreassen et al., 2014a; Andreassen, Nielsen, Pallesen, \& Gjerstad, in press), congruent with a review of estimates from previous studies on work addiction (Sussman, Lisha, \& Griffiths, 2011). The results of previous studies suggest that those of a younger age and/or in managerial positions are at higher risk of work addiction (Andreassen, Griffiths, Sinha, Hetland, \& Pallesen, 2016a). Taking into account the scope of the problem and its potential negative consequences, it is important to further identify risk factors of work addiction. Good assessment tools can aid early recognition of work addiction, which is important in terms of prevention and intervention.
From an addiction perspective, work addiction has been conceptualized and determined using seven core addiction symptoms: salience (preoccupation with work), mood modification (excessive working leading to reinforcing mood-specific changes), tolerance (increasing time spent working), withdrawal (adverse symptoms when unable to work), conflict (inter-/intrapersonal conflicts because of excessive work), relapse (returning to excessive working after a period of normal controlled working), and problems (resulting from excessive working such as health issues) (Brown, 1993; Griffiths, 2005; Leshner, 1997). Moreover, work addiction is unsurprisingly associated with time spent working (Andreassen, 2014), as well as key personality traits (systematically shown positive relationship with neuroticism, and mixed results regarding relationship with other Big Five traits) (Andreassen et al., 2013; Andreassen et al., 2016b; Andreassen et al., 2014a; Andreassen, Hetland, \& Pallesen, 2010; Atroszko, Andreassen, Griffiths, \& Pallesen, 2015; Atroszko, Andreassen, Griffiths, \& Pallesen, 2016a, b; Burke, Matthiesen, \& Pallesen, 2006; Clark, Lelchook, \& Taylor, 2010), and symptoms of psychological distress and psychiatric disorders (Andreassen et al., 2016a). While organizations may benefit in the short term from over-committed employees, work addiction has also been shown to be inversely related to work performance (Shimazu et al., 2010), and psychological wellbeing (Andreassen, Hetland, Molde, \& Pallesen, 2011; Atroszko, 2012; Shimazu, Demerouti, Bakker, Shimada, \& Kawakami, 2011; Shimazu \& Schaufeli, 2009). A recent paper shed new insights into the nature of work addiction, providing a theoretical background and empirical support for its relationship with attention deficit hyperactivity disorder (ADHD), suggesting that work addiction may act as a compensation of ADHD - a condition that often represents a hindrance in obtaining a professional career (see Andreassen et al., 2016a). To meet the expectations required to hold down a job and to avoid social stigma, individuals with ADHD may compensate for their inattentiveness, impulsivity, and hyperactivity by over-working.

Given that previous instruments assessing workaholism typically lack adequate consideration of all facets of addiction, the Bergen Work Addiction Scale (BWAS) was developed to overcome this weakness (Andreassen, Griffiths, Hetland, \& Pallesen, 2012). In accordance with the well-established biopsychosocial model of addiction, the BWAS assesses the seven aforementioned addiction elements (Brown, 1993; Griffiths, 2005; Leshner, 1997), and has demonstrated adequate validity and reliability in numerous studies carried out in Norway (Andreassen et al., 2012, $2013,2014)$ as well as in other countries such as Italy (Molino, 2012) and Hungary (Orosz et al., 2016). A one-factor solution has previously been found for the BWAS. Higher scores on the BWAS indicate 
a higher degree of work addiction. Scoring 4 (often) or 5 (always) on at least four out of seven items has been used as a cut-off for operationally defining individuals as work addicts in several previous studies (Andreassen et al., 2012; Andreassen et al., 2014a; Orosz et al., 2016).

Given this background, the aims of the present study were to adapt the BWAS into Polish, and to investigate the test reliability and validity of the scale in a large sample of Polish workers from a wide array of professions. Based on the existing literature it was hypothesized that:

- H1: The BWAS as an assessment of work addiction would have good reliability and validity, and unidimensional factor structure among the Polish sample.

- H2: Work addiction would be positively related to time spent working.

- H3: Work addiction would be inversely related to age.

- H4: Work addiction would be positively related to education and managerial positions.

- H5: Work addiction would be positively related to neuroticism.

- H6: Work addiction would be positively related to symptoms of depression and ADHD.

\section{PARTICIPANTS AND PROCEDURE}

\section{SAMPLE}

The sample comprised 723 employees (513 women [71.0\%] and 200 men [27.7\%]; 10 participants [1.4\%] did not report their sex) from a wide range of professions, including lawyers, managers, IT specialists, academics, researchers, medical doctors, psychologists, teachers, engineers, accountants, commercial trades, librarians and functionaries. Their mean age was 36.37 years $(S D=11.33)$, ranging from 20 to 79 years. In terms of professional position, 43 (5.9\%) participants were top-level managers, 56 (7.7\%) midlevel managers, 113 (15.6\%) had other managerial tasks, and $448(62.00 \%)$ participants held non-managerial positions (63 participants [8.7\%] did not report their managerial status). With regard to educational level, three participants $(0.4 \%)$ had up to 10 years of education (which corresponds to primary education), $126(17.4 \%)$ had between 10 and 15 years of education (which roughly corresponds to secondary education), $473(65.4 \%)$ had between 16 and 20 years of education (which more or less corresponds to a Bachelor's or Master's degree), 94 (13.00\%) had between 20 and 25 years of education, and 17 (2.3\%) participants had 26 or more years of education, respectively (10 participants [1.4\%] did not provide data on education). In terms of relationship status, 149 (20.6\%) were single (including divorced, separated and widows/widow- ers), and $570(78.8 \%)$ were either married or in a relationship (5 participants [0.7\%] did not report their status).

\section{INSTRUMENTS}

Demographics. Questions were asked concerning age, sex $(0=$ woman, $1=$ man $)$, relationship status $(0$ = married, partner, boyfriend, girlfriend, 1 = single, divorced, separated, widow/widower), years of completed education, professional position $(1=$ top-level manager, 2 = mid-level manager, 3 = other manager functions, 4 = no managerial duties), and total working hours per week (open-ended question). Since the reported years of completed education had several outliers (i.e., very high values) influencing skewness of the data distribution, a truncation procedure setting 26 years as the highest limit was applied. This roughly corresponded to obtaining a $\mathrm{PhD}$ and/or an additional Master's degree.

Health. Questions concerning current diseases or previously diagnosed diseases were asked (closedended response format), with an additional open-ended question for diseases not included in the list. Information about depression diagnosis $(n=38,5.3 \%)$ was also used in the analyses. However, no-one in the sample reported having been ever formally diagnosed with ADHD.

Bergen Work Addiction Scale (BWAS). The BWAS was used to assess work addiction (Andreassen et al., 2012). It includes seven items corresponding to the seven core addiction components - salience, mood modification, tolerance, withdrawal, conflict, relapse and problems (Brown, 1993; Griffiths, 2005; Leshner, 1997). The questions concerned symptoms experienced in the past 12 months. Responses were provided on a scale ranging from never (1) to always (5). Cronbach's $\alpha$ was .84 in the present study.

Adult ADHD Self-Report Scale (ASRS-Version 1.1). This scale comprises 18 questions (6 main items in part $\mathrm{A}$, and 12 additional items in part $\mathrm{B}$ ) of attention deficit hyperactivity disorder (ADHD) symptoms in adults (Kessler et al., 2005) based on criteria found in the latest (fifth) edition of the Diagnostic and Statistical Manual for Mental Disorders (DSM-5; American Psychiatric Association, 2013). All items are answered on a 5-point scale ranging from never (1) to very often (5), yielding an overall score from 18 to 90 . High scores indicate higher levels of ADHD symptoms among individuals. Scoring 3 (sometimes) or more on items 1-3, and 4 (often) or more on items 4-6 in part A, indicates clinical levels of ADHD. Cronbach's $\alpha$ for the ASRS-v1.1 was .82 in the present study.

Mini-InternationalPersonalityItem Pool(Mini-IPIP). The Mini-IPIP was used as a measure of the Five-Factor Model of personality (Donnellan, Oswald, Baird, \& Lucas, 2006). It comprises 20 items, four reflecting each
Work addiction in Poland 
Paweł Andrzej

Atroszko,

Ståle Pallesen,

Mark D. Griffiths,

Cecilie Schou

Andreassen of the following dimensions: extraversion (e.g., being outgoing, talkative), agreeableness (e.g., being sympathetic and warm), conscientiousness (e.g., being organized and structured), neuroticism (e.g., being nervous and moody), and intellect/imagination(e.g., being creative and intellectual), the latter being equal to the openness dimension. Each item is answered on a fivepoint scale ranging from very inaccurate (1) to very accurate (5). In the present study, the Cronbach's $\alpha$ for the five subscales were $.77, .75, .76, .71$ and .72 , respectively.

\section{PROCEDURE}

The BWAS was translated in a multistep procedure assuring linguistic equivalence of the Polish version. The BWAS was first translated from English to Polish by two translators (one lay person and one psychologist). The translations were then compared to each other and to the original version during a discussion session with the translators, a psychometrician, and psychology students. One Polish version was prepared and then back translated by two other independent translators (one lay person and one psychologist). During the next discussion session, back translations, the original version and the initial Polish version were compared. After adjustments the final Polish version was prepared and pretested on a small sample $(n=15)$ of diverse employees for any linguistic problems.

Data collection was based on convenience sampling. Employees were invited to participate anonymously in the study through their employers or directly. It was a pen-and-pencil cross-sectional study. The study took place from January 2014 to July 2016. No monetary or other material rewards were given for participation. Written informed consent was obtained from each participant.

\section{STATISTICAL ANALYSIS}

Factor analyses. A confirmatory factor analysis (CFA) using AMOS, version 23.0 was used to investigate the goodness of fit of the model with a one-factor solution of the BWAS. The maximum likelihood estimation method was used. Modification indices were investigated in order to improve model fit. Correlations between error terms of the indicators were introduced on the basis of modification indices when they were theoretically justified (Byrne, 2013).

Descriptive statistics. Internal consistencies, percentages, means, and standard deviations were calculated. The prevalence of work addiction was calculated (in accordance with the cut-off based on a polythetic approach (i.e., scoring 4 [often] or 5 [always] on at least four of the seven items), as well as how many work addicts who met the screening cut- off for borderline to clinical levels of ADHD (based on cut-offs for ASRS) and depression (based on reported current or previous diagnosis). The polythetic approach used in the present study is in line with modern psychiatric nosology (DSM-5; American Psychiatric Association, 2013).

Correlational analyses and group differences. To examine the associations between the study variables, Pearson's product-moment correlation coefficients were calculated for continuous variables, and point-biserial correlation coefficients for continuous and dichotomous variables. Chi-square tests were used to calculate and compare the prevalence rate of ADHD and depression in groups of work addicts and non-work addicts.

Regression analyses. Hierarchical multiple regression analysis was conducted. The dependent variable was work addiction (using the BWAS score). Independent variables comprised demographics (sex, age, relationship status, education) in Step 1, work-related variables (managerial position with high managerial status coded as the reference group, total work time) in Step 2, personality traits in Step 3, and ADHD and depression in Step 4. All tests were two-tailed, and the significance level was set to .05. For linear regression analysis, preliminary analyses were conducted to ensure no violation of the assumptions of normality, linearity, multicollinearity, and homoscedasticity. Analyses were conducted using IBM SPSS 23.

\section{ETHICS}

The study was carried out in accordance with the Declaration of Helsinki, and was approved by both the Norwegian Data Protection Official for Research, and the Research Ethics Committee at the Psychology Department of the University of Gdansk in Poland.

\section{RESULTS}

\section{FACTOR ANALYSES}

The 7-item BWAS model had a mediocre fit (minimum value of the discrepancy function divided by degrees of freedom [CMIN/DF] $=12.07$, root mean square error of approximation [RMSEA] $=.124(90 \%$ confidence interval $[\mathrm{CI}]=.11-.14)$, comparative fit in$\operatorname{dex}[\mathrm{CFI}]=.91$, Tucker-Lewis index $[\mathrm{TLI}]=.83)(\mathrm{Hu}$ $\&$ Bentler, 1999). The standardized regression weights ranged from .49 to .77 . Based on modification indices, correlations of error terms between Item 1 and Item 2 , Item 1 and Item 3, and Item 1 and Item 5 were allowed. The analysis of the content of items with correlated error terms suggested that they may assess general high devotion of time and energy to working, apart from the compulsive need to work, which is 
Table 1

Item wording, addiction component, percentage scoring 4 or 5 on particular item with $95 \%$ Cl, and standardized regression weights for items (7 item model/7 item model with correlated error terms)

\begin{tabular}{|c|c|c|c|c|}
\hline Item & Wording & $\begin{array}{l}\text { Addiction } \\
\text { component }\end{array}$ & $\begin{array}{l}\text { Percentage }(95 \% \mathrm{Cl}) \text {, } \\
\text { scoring } 4 \text { or } 5 \\
\end{array}$ & $\begin{array}{l}\text { Regression } \\
\text { weights }\end{array}$ \\
\hline BWAS1 & $\begin{array}{c}\text { Thought of how you could free up } \\
\text { more time to work? }\end{array}$ & Salience & $22.1 \%(19.1-25.1 \%)$ & $.49 / .40$ \\
\hline BWAS2 & $\begin{array}{l}\text { Spent much more time working than } \\
\text { initially intended? }\end{array}$ & Tolerance & $45.1 \%(41.4-48.7 \%)$ & $.72 / .70$ \\
\hline BWAS3 & $\begin{array}{l}\text { Worked in order to reduce feelings } \\
\text { of guilt, anxiety, helplessness and/or } \\
\text { depression? }\end{array}$ & $\begin{array}{l}\text { Mood } \\
\text { modification }\end{array}$ & $17.3 \%(14.5-20.0 \%)$ & $.56 / .54$ \\
\hline BWAS4 & $\begin{array}{l}\text { Been told by other to cut down on } \\
\text { work without listening to them? }\end{array}$ & Relapse & $21.7 \%(18.7-24.7 \%)$ & $.77 / .77$ \\
\hline BWAS5 & $\begin{array}{l}\text { Become stressed if you have been pro- } \\
\text { hibited from working? }\end{array}$ & Withdrawal & $14.7 \%(12.2-17.3 \%)$ & $.61 / .59$ \\
\hline BWAS6 & $\begin{array}{l}\text { Deprioritized hobbies, leisure activi- } \\
\text { ties, and/or exercise because of work? }\end{array}$ & Conflict & $29.1 \%(25.7-32.4 \%)$ & $.75 / .77$ \\
\hline BWAS7 & $\begin{array}{c}\text { Worked so much that it has negatively } \\
\text { influenced your health? }\end{array}$ & Problems & $16.3 \%(13.6-19.0 \%)$ & $.71 / .73$ \\
\hline
\end{tabular}

the core of work addiction. The 7-item BWAS with correlated error terms model had an acceptable fit: $\mathrm{CMIN} / \mathrm{DF}=5.76, \mathrm{RMSEA}=.081,90 \% \mathrm{CI}=.06-.10$, $\mathrm{CFI}=.97, \mathrm{TLI}=.95$. The standardized regression weights ranged from .40 to .77 . Correlations between error terms ranged from .19 to .29 . Table 1 shows the standardized regression weights for each of the items in both models as well as the percentage of respondents (with 95\% CI) scoring 4 (often) or 5 (always) on a particular item.

\section{GROUP DIFFERENCES}

The prevalence of work addiction in the current sample was estimated as $17.4 \%(n=125)$. Table 2 presents the number of items with a score of 4 (often) or 5 (always). Using polythetic scoring, the following results were obtained: $14.4 \%$ of work addicts met the screening cut-off for clinical levels of ADHD compared to $5.1 \%$ of non-work addicts $\left(\chi_{d f=1, N=719}^{2}=14.49\right.$, $p<.001)$, and $10.4 \%(n=13)$ of work addicts reported having ever been diagnosed with depression compared to $4.2 \%$ for non-work addicts $\left(\chi_{d f=1 . N=719}^{2}=7.91\right.$, $p=.005)$. These results demonstrate significant differences between work addicts and non-work addicts in terms of clinical states.

\section{DESCRIPTIVE STATISTICS}

Table 3 presents mean scores and standard deviations for all study variables as well as their interrelation- ships. Work addiction correlated positively with total work time, neuroticism, intellect/imagination, symptoms of depression and ADHD, and correlated negatively with conscientiousness.

\section{WORK ADDICTION PREDICTORS}

The regression analysis for work addiction showed that the independent variables explained a total of $21.3 \%$ of the variance of work addiction $\left(F_{15,598}=10.77\right.$, $p<.001$ ) (see Table 4).

Basic demographics (age, sex, relationship status, education) were entered at Step 1, and explained only

Table 2

Prevalence of work addiction in the current sample

\begin{tabular}{lrc}
\hline $\begin{array}{l}\text { Number of items with } \\
\text { score } 4 \text { (often) or }\end{array}$ & $\begin{array}{c}\text { Estimated } \\
\text { prevalence }\end{array}$ & $95 \% \mathrm{Cl}$ \\
\hline (always) & $39.1 \%$ & $35.5-42.7 \%$ \\
\hline 0 items & $16.8 \%$ & $14.1-19.6 \%$ \\
1 item & $16.4 \%$ & $13.7-19.1 \%$ \\
2 items & $10.3 \%$ & $8.1-12.5 \%$ \\
3 items & $7.1 \%$ & $5.2-9.0 \%$ \\
4 items & $5.6 \%$ & $3.9-7.2 \%$ \\
5 items & $3.6 \%$ & $2.6-5.0 \%$ \\
6 items & $1.1 \%$ & $0.3-1.9 \%$ \\
\hline items & & \\
\hline
\end{tabular}

Work addiction in Poland 


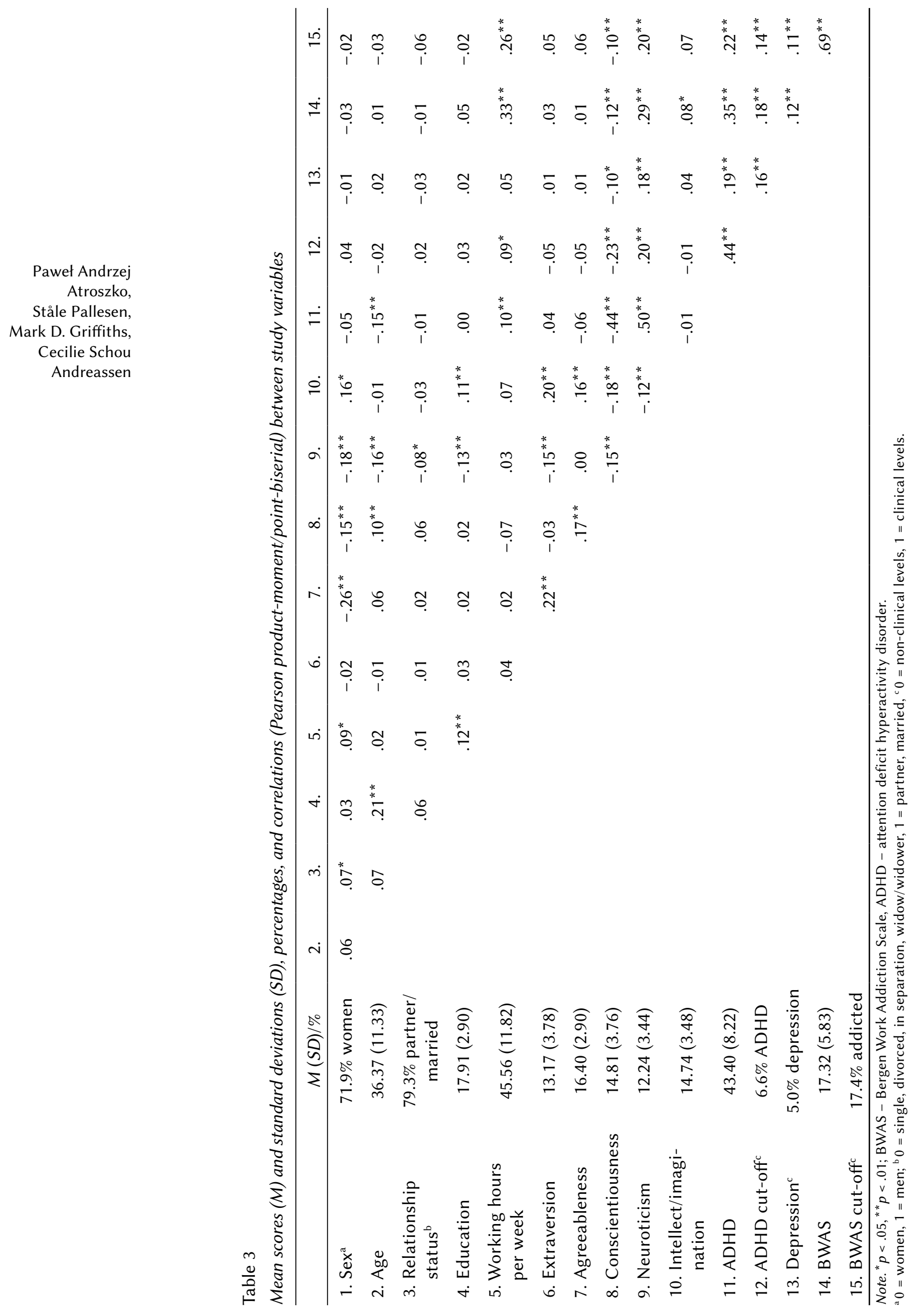


$0.6 \%$ of the variance of work addiction $\left(F_{4,609}=.91\right.$, $p=.461$ ). Work-related variables (managerial position and working hours per week) were entered at Step 2, and additionally explained $8.4 \%$ of the variance of work addiction, $\Delta R^{2}=.08, \Delta F_{4,605}=14.05$, $p<.001$. Personality traits were entered at Step 3, and explained an additional $9.1 \%$ of the variance of work addiction, $\Delta R^{2}=.09, \Delta F_{5,600}=13.37, p<.001$, whereas the psychiatric symptoms (ADHD and depression) entered at Step 4 additionally explained a further $3.1 \%$ of the variance of work addiction, $\Delta R^{2}=.03$, $\Delta F_{2,598}=11.80, p<.001$. ADHD was significant $(\beta=.22)$ and contributed the most in this step. In this final step of the regression model, ADHD and working hours $(\beta=.19)$, neuroticism $(\beta=.18)$, mid-level manager position $(\beta=.08)$ and low managerial status $(\beta=.14)$ were significant predictors of work addiction.

\section{DISCUSSION}

The results of the present study were generally similar to those reported in previous studies concerning the structure of the BWAS and the associations between work addiction and psychiatric symptoms. The BWAS (Andreassen et al., 2012) was translated into Polish and validated in a sample of employees representing many professions. Factor-analytical results showed that the original 7-item one factor solution had a mediocre fit to the data. Examination of the modification indices showed that the error term of Item 1 "How often do you think of how you can free up more time to work?" (i.e., salience) had substantial covariance with error terms of Item 2 (tolerance), Item 3 (mood modification) and Item 5 (withdrawal), suggesting that Item 1 may be assessing general high

Table 4

Results of hierarchical multiple regression analyses in which age, sex, relationship status, education, managerial position, working hours per week, personality traits, depression, and ADHD were regressed upon the scores on the BWAS

\begin{tabular}{|c|c|c|c|}
\hline Step & Predictor & $\beta$ & $\Delta R^{2}$ \\
\hline \multirow[t]{4}{*}{1} & $\operatorname{Sex}^{a}$ & -.04 & .01 \\
\hline & Age & .01 & \\
\hline & Relationship status ${ }^{b}$ & -.01 & \\
\hline & Education & .07 & \\
\hline \multirow[t]{8}{*}{2} & Sex $^{a}$ & -.08 & $.08^{* *}$ \\
\hline & Age & -.01 & \\
\hline & Relationship status ${ }^{b}$ & -.02 & \\
\hline & Education & .06 & \\
\hline & Managerial status: high & .05 & \\
\hline & Managerial status: middle & $.09^{*}$ & \\
\hline & Managerial status: low & $.15^{* *}$ & \\
\hline & Working hours per week & $.22^{* *}$ & \\
\hline \multirow[t]{9}{*}{3} & $\operatorname{Sex}^{a}$ & -.04 & $.09^{* *}$ \\
\hline & Age & .03 & \\
\hline & Relationship status $^{\mathrm{b}}$ & .00 & \\
\hline & Education & $.08^{*}$ & \\
\hline & Managerial status: high & .05 & \\
\hline & Managerial status: middle & $.09^{*}$ & \\
\hline & Managerial status: low & $.14^{* *}$ & \\
\hline & Working hours per week & $.21^{* *}$ & \\
\hline & Extraversion & .02 & \\
\hline
\end{tabular}

\begin{tabular}{cccc}
\hline Step & Predictor & $\beta$ & $\Delta R^{2}$ \\
\hline & Agreeableness & .04 & \\
& Conscientiousness & -.07 & \\
Neuroticism & $.29^{* *}$ & \\
4 & Intellect/imagination & .06 & \\
& Sex & -.03 & $.03^{* *}$ \\
& Age & .04 &
\end{tabular}

Work addiction in Poland

Note. ${ }^{*} p<.05,{ }^{* *} p<.01$; BWAS - Bergen Work Addiction Scale, ADHD - attention deficit hyperactivity disorder.

${ }^{\mathrm{a}} 0=$ women, $1=$ men; ${ }^{\mathrm{b}} 0=$ single, divorced, in separation, widow/widower, $1=$ partner, married, ${ }^{\mathrm{c}} 0=$ non-clinical levels, $1=$ clinical levels. 
Paweł Andrzej Atroszko, Ståle Pallesen, Mark D. Griffiths, Cecilie Schou Andreassen devotion to time and energy to working, as opposed to the compulsive need to work which is the core of work addiction. The 7-item one-factor solution of BWAS with correlated error terms had acceptable fit (part of H1). All factor loadings were significant, with standardized values above .40 .

In the present sample, the prevalence of work addiction (17.4\%) was significantly higher than reported in previous studies (e.g., $8.3 \%$ reported by Andreassen et al., 2014a and 7.3\% reported by Andreassen et al., in press). This may be related to the fact that the present study sample comprised a relatively high proportion of participants in managerial positions and with high education, variables that are both associated with work addiction (Andreassen, 2014; Andreassen et al., in press). However, this finding could also reflect the fact that work addiction may be more prevalent in Poland compared to Norway or other Western countries (Sussman et al., 2011) due to specific characteristics of the Polish labor market (i.e., high demands on workers and employment instability; see Atroszko et al., 2016a, b).

Work addiction was positively associated with working hours (supporting H2) and managerial positions (supporting part of $\mathrm{H} 4$ ), which is congruent with previous research and confirms the validity of the BWAS (supporting H1) (Andreassen, 2014; Andreassen et al., 2016a). Although time spent working is not a defining criterion for work addiction in itself, work addicts still tend to spend more time working than non-work addicts. Also, work addiction was more prevalent among those who had managerial functions than those who did not. However, work addiction was unrelated to age and education (H3 and part of $\mathrm{H} 4$ : not supported). Again, this may be due to the sampling approach, which may have contributed to a more homogeneous sample. Effect sizes for age and education in relation to work addiction tend in previous studies to be generally small, and are mainly found in large, representative (Andreassen et al., 2014a) or large, diverse samples (Andreassen et al., 2016a).

\section{WORK ADDICTION AND PERSONALITY}

A positive association between work addiction and neuroticism was found (supporting H5), which supports the validity of the BWAS (part of $\mathrm{H} 1$ : supported) (Andreassen et al., 2014a). This finding is congruent with previous studies - consistently showing a negative relationship between emotional stability and work addiction (Andreassen et al., 2013; Andreassen et al., 2014a; Andreassen et al., 2010; Atroszko et al., 2015; Burke et al., 2006; Clark et al., 2010). Longitudinal studies have also suggested neuroticism to be a predictor over time of aggravating symptoms of work addiction (Andreassen et al., 2016b) and study addiction (viewed as a precursor to work addiction;
Atroszko et al., 2016a, b). Extraversion, intellect/imagination, agreeableness and conscientiousness were unrelated to work addiction, which is congruent with some previous studies (e.g., Andreassen et al., 2014a; Andreassen et al., 2010; Atroszko, 2015; Atroszko et al., 2015; Burke et al., 2006; Clark et al., 2010).

\section{WORK ADDICTION AND PSYCHOPATHOLOGY}

Work addiction was positively related to ADHD (supporting H6), replicating the finding from the recent study by Andreassen et al. (2016a), providing further substantiation for the hypothesis that work addiction for some may be a way to compensate for ADHD symptoms. The present study and the study by Andreassen et al. (2016a) both found that work addicts were almost three times more likely to report clinical levels of ADHD than non-work addicts. Work addiction was positively related to depression (supporting H6), with reports from work addicts being two times more likely to have been ever diagnosed with depression than non-work addicts. This result replicated findings (Andreassen et al., 2016a) in which depression was assessed with the Hospital Anxiety and Depression Scale (HADS) and supports the validity of the BWAS (supporting H1).

Taking the current findings into consideration, more attention should be directed towards identifying adults with ADHD symptoms and to explore their coping mechanisms (e.g., overworking). In the present sample, one out of three of those reporting clinical ADHD levels also met the cut-off criteria for work addiction status. These individuals should be provided with appropriate work-related interventions. Taking into account the fact that the medication has only short-term effects, treatment adherence is often low and, most importantly, the medication has serious side effects, there are more studies carried out on the effectiveness of cognitive-behavioral approaches, especially in adults, including mindfulness-based practices (Meppelink, de Bruin, \& Bögels, 2016; Mitchell, Zylowska, \& Kollins, 2015; Shonin, Van Gordon, \& Griffiths, 2014; Van Gordon et al., 2017). At the same time, awareness about the relationship between ADHD and work addiction should be raised, especially in the context of work-life balance and earlier education to prevent negative stigmatization and discrimination of people affected by ADHD - a condition which may lead them into excessive and compulsive working in an attempt to compensate.

\section{STRENGTHS AND LIMITATIONS}

In terms of limitations, it should be noted that the present study was based on a convenience sample, predominantly women. Therefore, the results cannot 
be generalized to other populations without some reservation. All data were based on self-report, and the usual weaknesses of such data (such as social desirability bias, recall biases, common method bias, etc.) should be noted. The design was cross-sectional, and therefore it is impossible to draw causal inferences. Furthermore, only one measure of work addiction was used, which prevented calculation of test-retest relationships. Regarding the strengths of the present study, it is the first study (as far as the authors are aware) to investigate the validity and reliability of the BWAS in Polish and to investigate its relationship with psychopathology in a Polish sample of employees from a wide range of professions. It is also only the second study (worldwide) investigating the relationship between work addiction and ADHD. The study was conducted in a relatively large and diverse sample, providing high statistical power. Several variables comprising possible antecedents of work addiction were included, such as valid and reliable measures of personality and ADHD. Consequently, this study significantly adds to the existing literature, specifically on work addiction and more generally on behavioral addictions. Furthermore, the present study provides valid, reliable, and convenient assessment of work addiction both for research purposes and for screening individuals at risk of work addiction.

\section{CONCLUSIONS AND FUTURE RESEARCH DIRECTIONS}

The BWAS demonstrated good psychometric properties in a Polish sample. As expected, work addiction appeared to be related to psychopathology. However, the results of the present study should be corroborated in other Polish samples. Studies using representative samples of employees would aid the examination of the incidence and prevalence of work addiction in Poland. Also, studies examining potential cultural and socioeconomic factors related to work addiction are necessary, as some differences in results appear across countries. Longitudinal studies are warranted as such data may provide useful information in terms of possible developmental risk factors of work addiction, including investigating the mechanisms underlying the relationship between $\mathrm{ADHD}$ and work addiction. Investigating the relationship of work addiction with psychopathology using workaholism measures developed within an organizational context may provide more data on convergence and/or divergence of such measures.

\section{References}

American Psychiatric Association. (2013). Diagnostic and statistical manual of mental disorders ( $5^{\text {th }}$ ed.). Arlington, VA: American Psychiatric Publishing.
Andreassen, C. S. (2014). Workaholism: An overview and current status of the research. Journal of Behavioral Addictions, 3, 1-11.

Andreassen, C. S., Griffiths, M. D., Hetland, J., Kravina, L., Jensen, F., \& Pallesen, S. (2014). The prevalence of workaholism: A survey study in a nationally representative sample of Norwegian employees. PLoS One, 9, e102446. doi: 10.1371/ journal.pone. 0102446

Andreassen, C. S., Griffiths, M. D., Gjertsen, S., Krossbakken, E., Kvam, S., \& Pallesen, S. (2013). The relationships between behavioral addictions and the five-factor model of personality. Journal of Behavioral Addictions, 2, 90-99. doi: 10.1556/JBA.2.2013.003

Andreassen, C. S., Griffiths, M. D., Hetland, J., \& Pallesen, S. (2012). Development of a work addiction scale. Scandinavian Journal of Psychology, 53, 265-272. doi: 10.1111/sjop.2012.53.issue-3

Andreassen, C.S., Griffiths, M. D., Sinha, R., Hetland, J., \& Pallesen, S. (2016) The relationships between workaholism and symptoms of psychiatric disorders: A large-scale cross-sectional study. PLoS One, 11: e0152978. doi: 10.1371/journal.pone.0152978

Andreassen, C. S., Bjorvatn, B., Moen, B. E., Waage, S., Magerøy, N., \& Pallesen, S. (2016). A longitudinal study of the relationship between the five-factor model of personality and workaholism. TPM - Testing, Psychometrics, Methodology in Applied Psychology, 23, 285-298.

Andreassen, C. S., Hetland, J., \& Pallesen, S. (2014). Psychometric assessment of workaholism measures. Journal of Managerial Psychology, 29, 7-24. doi: 10.1108/JMP-05-2013-0143

Andreassen, C. S., Nielsen, M. B., Pallesen, S., \& Gjerstad, J. (in press). The relationship between psychosocial work variables and workaholism: Findings from a nationally representative survey. International Journal of Stress Management.

Andreassen, C. S., \& Pallesen, S. (2016). Workaholism: An addiction to work. In V. R. Preedy (ed.), Neuropathology of drug addictions and substance misuse. Volume 3 (pp. 972-983). London, UK: Academic Press. doi: 10.1016/B978-0-12-800634-4.00096-2

Andreassen, C. S., Hetland, J., Molde, H., \& Pallesen, S. (2011). 'Workaholism' and potential outcomes in well-being and health in a cross-occupational sample. Stress and Health, 27, E209-E214.

Andreassen, C. S., Hetland, J., \& Pallesen, S. (2010). The relationship between 'workaholism', basic needs satisfaction at work and personality. European Journal of Personality, 24, 3-17.

Atroszko, P. A. (2012). Research on behavioural addictions: Work addiction. In M. Baranowska-Szczepańska \& M. Gołaszewski (eds.), Modern research trends of young scientists: current status, problems and prospects (pp. 11-24). Poznań: Wydawnictwo Naukowe Wyższej Szkoły Handlu i Usług.
Work addiction in Poland 
Atroszko, P. A. (2015). The structure of study addiction: Selected risk factors and the relationship with stress, stress coping and psychosocial functioning (Unpublished doctoral thesis). University of Gdansk, Gdansk, Poland.

Atroszko, P. A., Andreassen, C. S., Griffiths, M. D., \& Pallesen, S. (2015). Study addiction - A new area of psychological study: Conceptualization, assessment, and preliminary empirical findings. Journal of Behavioral Addictions, 4, 75-84. doi: 10.1556/2006.4.2015.007
Paweł Andrzej Atroszko, Ståle Pallesen, Mark D. Griffiths, Cecilie Schou Andreassen
Atroszko, P. A., Andreassen, C. S., Griffiths, M. D., \& Pallesen, S. (2016a). Study addiction: A crosscultural longitudinal study examining temporal stability and predictors of its changes. Journal of Behavioral Addictions, 5, 357-362. doi: 10.1556/2006.5.2016.024

Atroszko, P. A., Andreassen, C. S., Griffiths, M. D., \& Pallesen, S. (2016b). The relationship between study addiction and work addiction: A cross-cultural longitudinal study. Journal of Behavioral Addictions, 5, 708-714. doi: 10.1556/2006.5.2016.024

Birkeland, I. K., \& Buch, R. (2015). The dualistic model of passion for work: Discriminate and predictive validity with work engagement and workaholism. Motivation and Emotion, 39, 392-408. doi: 10.1007/s11031-014-9462-x

Brown, R. I. F. (1993). Some contributions of the study of gambling to the study of other addictions. In W. R. Eadington \& J. A. Cornelius (eds.), Gambling behavior and problem gambling (pp. 241-272). Reno, NV: University of Nevada.

Burke, R. J., \& Fiksenbaum, L. (2009). Work motivations, work outcomes, and health: Passion versus addiction. Journal of Business Ethics, 84, 257-263. doi: 10.1007/s10551-008-9697-0

Burke, R. J., Matthiesen, S. B., \& Pallesen, S. (2006). Personality correlates of workaholism. Personality and Individual Differences, 40, 1223-1233.

Byrne, B. M. (2013). Structural equation modeling with AMOS: Basic concepts, applications, and programming $\left(2^{\text {nd }}\right.$ ed. $)$. New York, NY: Routledge.

Clark, M. A., Lelchook, A. M., \& Taylor, M. L. (2010). Beyond the Big Five: how narcissism, perfectionism, and dispositional affect relate to workaholism. Personality and Individual Differences, 48, 786-791.

Clark, M. A., Michel, J. S., Zhdanova, L., Pui, S. Y., \& Baltes, B. B. (2016). All work and no play? A meta-analytic examination of the correlates and outcomes of workaholism. Journal of Management, 42, 1836-1873. doi: 10.1177/0149206314522301

Donnellan, M. B., Oswald, F. L., Baird, B. M., \& Lucas, R. E. (2006). The Mini-IPIP scales: Tiny-yet-effective measures of the big five factors of personality. Psychological Assessment, 18, 192-203.

Falco, A., Girardi, D., Kravina, L., Trifiletti, E., Bartolucci, G. B., Capozza, D., \& De Carlo, N. A. (2013).
The mediating role of psychophysic strain in the relationship between workaholism, job performance, and sickness absence. A longitudinal study. Journal of Occupational and Environmental Medicine, 55, 1255-1261.

Griffiths, M. D. (2005). A 'components' model of addiction within a biopsychosocial framework. Journal of Substance Use, 10, 191-197. doi: 10.1080/14659890500114359

Griffiths, M. D. (2011). Workaholism: A $21^{\text {st }}$ century addiction. The Psychologist: Bulletin of the British Psychological Society, 24, 740-744.

Hu, L. T., \& Bentler, P. M. (1999). Cutoff criteria for fit indexes in covariance structure analysis: conventional criteria versus new alternatives. Structural Equation Modeling: A Multidisciplinary Journal, 6, 1-55.

Karanika-Murray, M., Duncan, N., Pontes, H., \& Griffiths, M. D. (2015). I belong therefore I am: An empirical investigation of work engagement, organizational identification and job satisfaction. Journal of Managerial Psychology, 30, 1019-1033. doi: 10.1108/JMP-11-2013-0359

Karanika-Murray, M., Pontes, H. M., Griffiths, M. D., \& Biron, C. (2015). Sickness presenteeism determines job satisfaction via affective-motivational states. Social Science and Medicine, 139, 100-106. doi: 10.1016/j.socscimed.2015.06.035

Kessler, R. C., Adler, L., Ames, M., Demler, O., Faraone, S., Hiripi, E., ...Walters, E. E. (2005). The World Health Organization Adult ADHD Self-Report Scale (ASRS): A short screening scale for use in the general population. Psychological Medicine, 35, 245-256. pmid: 1584168

Koob, G. F., \& Volkow, N. D. (2010). Neurocircuitry of addiction. Neuropsychopharmacology, 35, 217-238. doi: 10.1038/npp.2009.110

Leshner, A. I. (1997). Addiction is a brain disease, and it matters. Science, 278, 45-47. doi: 10.1126/ science.278.5335.45

Meppelink, R., de Bruin, E. I., \& Bögels, S. M. (2016). Meditation or medication? Mindfulness training versus medication in the treatment of childhood ADHD: A randomized controlled trial. BMC Psychiatry, 16, 267.

Mitchell, J. T., Zylowska, L., \& Kollins, S. H. (2015). Mindfulness meditation training for attention-deficit/hyperactivity disorder in adulthood: Current empirical support, treatment overview, and future directions. Cognitive and Behavioral Practice, 22, 172-191.

Molino, M. (2012). Workaholism: Definitions, measures, and dynamics (Unpublished doctoral thesis). University of Torino, Torino, Italy.

Orosz, G., Loránd, E., Dombi, E., Andreassen, C. S., Griffiths, M. D., \& Demetrovics, Z. (2016a). Analyzing models of work addiction: Single factor and bi-factor models of the Bergen Work Addiction 
Scale. International Journal of Mental Health and Addiction, 14, 662-671. doi: 10.1007/s11469-0159613-7

Orosz, G., Tóth-Király, I., Bőthe, B., \& Melher, D. (2016b). Too many swipes for today: The development of the Problematic Tinder Use Scale (PTUS). Journal of Behavioral Addictions, 5, 518-523.

Quinones, C., \& Griffiths, M. D. (2015). Addiction to work: A critical review of the workaholism construct and recommendations for assessment. Journal of Psychosocial Nursing and Mental Health Services, 10, 48-59.

Quinones, C., Griffiths, M. D., \& Kakabadse, N. (2016). Compulsive Internet use and workaholism: An exploratory two-wave longitudinal study. Computers in Human Behavior, 60, 492-499. doi: 10.1016/j.chb.2016.02.060

Shimazu, A., Demerouti, E., Bakker, A. B., Shimada, K., \& Kawakami, N. (2011). Workaholism and well-being among Japanese dual-earner couples: A spillover-crossover perspective. Social Science and Medicine, 73, 399-409.

Shimazu, A., \& Schaufeli, W. B. (2009). Is workaholism good or bad for employee well-being? The distinctiveness of workaholism and work engagement among Japanese employees. Industrial Health, 47, 495-502.

Shimazu, A., Schaufeli, W. B., \& Taris, T. W. (2010). How does workaholism affect worker health and performance? The mediating role of coping. International Journal of Behavioural Medicine, 17, 154-160.

Shimazu, A., Schaufeli, W. B., Kamiyama, K., \& Kawakami, N. (2015). Workaholism vs. work engagement: The two different predictors of future well-being and performance. The International Journal of Behavioral Medicine, 22, 18-23. doi: 10.1007/s12529-014-9410-x. pmid:24696043

Shonin, E., Van Gordon, W., \& Griffiths M. D. (2014). The treatment of workaholism with Meditation Awareness Training: A case study. Explore: Journal of Science and Healing, 10, 193-195. doi: 10.1016/j. explore.2014.02.004

Sussman, S., Lisha, N., \& Griffiths, M. (2011). Prevalence of the addictions: A problem of the majority or the minority? Evaluation \& the Health Professions, 34, 3-56.

Vallerand, R. J., Paquet, Y., Philippe, F. L., \& Charest, J. (2010). On the role of passion for work in burnout: A process model. Journal of Personality, 78, 289-312.

van Beek, I., Hu, Q., Schaufeli, Q. B., Taris, T. W., \& Schreurs, B. H. J. (2012). For fun, love, or money: What drives workaholic, engaged, and burnedout employees at work? Applied Psychology: An International Review, 61, 30-55.

van Beek, I., Taris, T. W., Schaufeli, W. B., \& Brenninkmeijer, V. (2014). Heavy work investment: Its motivational make-up and outcomes. Journal of Managerial Psychology, 49, 46-62.

van Beek, I., Taris, T. W., \& Schaufeli, W. B. (2011). Workaholic and work engaged employees: Dead ringers or worlds apart? Journal of Occupational Health Psychology, 16, 468-482.

Van Gordon, W., Shonin, E., Dunn, T. J., Garcia-Campayo, J., Marcelo, M. P., Demarzo, M. M. P., \& Griffiths, M. D. (2017). Meditation awareness training for the treatment of workaholism: A non-randomised controlled trial. Journal of Behavioral Addictions. Epub ahead of print. doi: 10.1556/2006.6.2017.021
Work addiction in Poland 